\title{
PENGARUH KARAKTERISTIK INDIVIDU, KOMUNIKASI EFEKTIF DAN KEPUASAN KERJA TERHADAP KINERJA KARYAWAN (studi pada PT Tambang Batubara Bukit Asam)
}

\author{
Hartiwi Agustina*, Muliyadi Jaya, Yudi Pungan \\ STIE Palangkaraya \\ E-mail: hartiwi@gmail.com
}

\begin{abstract}
This study aimed to examine the influence of individual characteristics, effective communication, and job satisfaction on the performance of employees of PT Tambang Batubara Bukit Asam. The problem in this study is causal causal problems which are reflected in the hypothesis model. The sample involved was 80 respondents using purposive sampling sampling technique. The analytical tool used by Multiple Linear Regression. The results of the study were found: (1) the effect of individual characteristics on the performance of employees of PT Tambang Batubara Bukit Asam, based on the t-count, indicating that individual characteristics have a tcount of 4.381, while t table is 1.665. So $t_{\text {calc }}>t_{\text {table }}(4.381>1.665)$ can be concluded that individual characteristics $(X 1)$ have a significant effect on employee performance $(Y)$, (2) the effect of effective communication on the performance of employees of PT Tambang Batubara Bukit Asam, based on the tcount indicating effective communication has a tcount of 2,434 , while the table is 1,665 . So $t_{\text {calc }}>t_{\text {table }}(2,434>1,665)$ can be concluded that effective communication (X2) has a significant effect on employee performance (Y), (3) the effect of job satisfaction on the performance of employees of PT Tambang Batubara Bukit Asam, based on the t-count indicating satisfaction has a tcount of 3,419, while the table is 1.665. So $t_{\text {calc }}>t_{\text {table }}(3,419>1,665)$ can be concluded that satisfaction (X3) has a significant effect on employee performance $(Y)$.
\end{abstract}

Keywords: Individual characteristics, effective communication, satisfaction, performance

\begin{abstract}
Abstrak
Penelitian ini bertujuan menganalisis pengaruh karakteristik individu, komunikasi efektif, dan kepuasan kerja terhadap kinerja karyawan PT Tambang Batubara Bukit Asam. Permasalah dalam penelitian ini merupakan permasalahan kausal sebab akibat yang tercermin dalam model hipotesis. Sampel yang terlibat sebesar 80 responden dengan menggunakan teknik pengambilan sampel purposive sampling. Alat analisis yang digunakan Regresi Linier Berganda. Hasil penelitian ditemukan: (1) pengaruh karakteristik individu terhadap kinerja karyawan PT Tambang Batubara Bukit Asam, berdasarkan nilai thitung menunjukkan karakteristik individu mempunyai thitung sebesar 4,381, sedangkan ttabel sebesar 1,665. Jadi thitung > ttabel $(4,381>1,665)$ dapat disimpulkan bahwa karakteristik individu (X1) berpengaruh signifikan terhadap kinerja karyawan (Y), (2) pengaruh komunikasi efektif terhadap kinerja karyawan PT Tambang Batubara Bukit Asam, berdasarkan nilai thitung menunjukkan komunikasi efektif mempunyai thitung sebesar 2,434, sedangkan ttabel sebesar 1,665. Jadi thitung > ttabel $(2,434>1,665)$ dapat disimpulkan bahwa komunikasi efektif (X2) berpengaruh signifikan terhadap kinerja karyawan (Y), (3) pengaruh kepuasan kerja terhadap kinerja karyawan PT Tambang Batubara Bukit Asam, berdasarkan nilai thitung menunjukkan kepuasan mempunyai thitung sebesar 3,419, sedangkan ttabel sebesar 1,665. Jadi thitung > ttabel $(3,419>1,665)$ dapat disimpulkan bahwa kepuasan (X3) berpengaruh signifikan terhadap kinerja karyawan (Y).
\end{abstract}

Kata kunci: Karakteristik individu, Komunikasi efektif, Kepuasan, Kinerja 


\section{PENDAHULUAN}

Organisasi sebagai tempat bagi orang-orang dalam memenuhi kebutuhan hidup yang berbeda-beda untuk bekerjasama mencapai tujuan bersama. Didalam kerjasama melibatkan usaha-usaha koordinasi dan interaksi antar individu yang berbeda-beda. Sementara individu-individdu didalam organisasi berasal dari lingkungan yang berbeda-beda yang membawa faktor fisiologi, psikologi dan biografi organisasi. Perbedaan individu ini dilihat dari karakteristiknya dengan menggunakan unsurunsur dari fisiologi dan psikologis dalam melakukan kegiatan-kegiatan suatu organisasi.

Pandangan tersebut bahwa organisasi dapat mencapai tujuan dengan melakukan kegiatan yang telah direncanakan, dikoordinasikan dan dievaluasi dengan melalui proses komunikasi. Dengan media komunikasi masing-masing individu mengetahui segala kewajiban dan tanggungjawabnya. Komunikasi dipandang sebagai suatu proses yang peranannya sangat besar yaitu komunikasi dapat memperlihatkan suatu perubahan yang dapat terjadi secara langsung maupun secara tidak langsung (Muhammad, 2000).

Upaya mencapai komunikasi efektif dalam pemindahan informasi dan kemampuan pemahaman antar individu, antar pengirim dan penerima informasi hendaknya memiliki kesamaan yaitu mengenai sifat individu, pengalaman, lingkungan dan latar belakang social budaya sehingga dapat menyerap informasi secara tepat. Kegiatankegiatan komunikasi sebagai pelaksanaan dari sistem komunikasi atau program komunikasi dapat diukur, sehingga kualitas dan kinerja eksekutif, pejabat dan staf komunikasi sapat diketahui dan apabila diperlukan dapat diperbaiki secara sistematik, agar efektifitas dan efisiensi komunikasi dapat meningkat (Hardjana, 2000). Dapat dikatakan bahwa dengan proses komunikasi ini memungkinkantujuan yang ingin dicapai setiap orang tentu berbeda-beda, namun pada dasarnya jika dikaitkan dengan kegiatan dalam organisasi, tentunya ingin memperoleh kepuasan kerja dan meningkatkan kinerja karyawan.

Menurut Frank M. Corrado, terdapat dua kebutuhan informasi yaitu pertama, informasi mengenai bisnis pada unitnya sendiri, karyawan perlu mengetahui kemana arah organisasi, bagaimana upaya organisasi untuk mencapainya, apa peran karyawan dalam proses tersebut. Kedua adalah informasi pribadi seperti berapa gaji, tunjangan yang diterima, bagaimana penilaian prestasi dan pengembangan karir dan bagaimana agar karyawan memahami situasi kerjanya. Dari uraian tersebut terkandung arti bahwa persepsi sangat penting dalam keterbukaan komunikasi

Persepsi itu sendiri dipengaruhi oleh faktor-faktor fungsional yang berasal dari kebutuhan, pengalaman masa lalu yang termasuk dalam faktor-faktor personal. Dalam kegiatan komunikasi faktor fungsional mempengaruhi bagaimana orang menerima pesan, baik dari sesama karyawan maupun atasan. Dengan demikian keberhasilan seseorang dalam berkomunikasi sangat tergantung pada pembentukan persepsi dirinya sendiri. Pada aspek lain, komunikasi efektif akan menghasilkan kepuasa pribadi yang terlibat dalam komunikasi. Karena melalui komunikasi efektif, karyawan telah menyampaikan apa yang diinginkannya dan atasan juga telah mendapatakan apa yang diinginkan dari bawahan, demikian pula sebaliknya kepuasan karyawan terhadap komunikasi yang berlangsung efektif akan mempengaruhi kerja dan kinerja di dalam organisasi. 


\section{TINJAUAN PUSTAKA}

\section{Landasan Teori}

Karakteristik Individu

Karakteristik individu meliputi kemampuan, perspesi, sikap, pengalaman dan motivasi.. Kemampuan merupakan kapasitas individu untuk mengerjakan berbagai tugas, kemampuan memiliki pengaruh langsung pada tingkat kepuasan dan tingkat kinerja seseorang sebagaimana dinyatakan oleh Robbins (2003), agar karyawan dapat melakukan kerja dengan baik, maka memerlukan suatu kesesuaian dengan pekerjaannya, kesesuaian dapat diperoleh dengan cara mencocokkan antara sifat pekerjaan dengan kemampuan karyawan. Dengan demikian kinerja karyawan dapat ditingkatkan dengan adanya kesesuaian antara pekerjaan dengan kemampuan. Persepsi adalah pengalaman tentang obyek, peristiwa atau hubungan yang diperoleh dengan menyimpulkan informasi dan menafsirkan pesan. Robbins (2003) mengemukakan bahwa persepsi merupakan proses dimana individu-individu mengorganisasikan dan menafsirkan kesankesan indra mereka agar memberikan makna bagi lingkungan mereka. Sikap sebagai perasaan positif atau negatif, atau keadaan mental yang selalu dipersiapkan, dipelajari dan diatur melalui pengalaman dan memberikan pengaruh khusus pada respon seseorang terhadap orang, obyek-obyek dan keadaan. Azwar (2000) berpendapat individu bereaksi membentuk pola sikap tertentu terhadap obyek psikologis yang dihadapinya, diantaranya faktor yang mempengaruhi pembentukan sikap adalah pengalaman pribadi, kebudayaan, media massa serta faktor emosi dalam diri seseorang. Pengalaman kerja yang dimiliki seseorang berbeda-beda, semakin lama seseorang karyawan bekerja akan semakin berpengalaman, memberikan kemahiran dan terampil dalam bidangnya. Dengan pengalaman kerja, karyawan akan mengembangkan sikap mengenai keadilan, penggajian, tinjauan prestasi, kemampuan manajerial, rancangan pekerjaan dan afiliasi kelompok kerja. Motivasi adalah kemampuan untuk berbuat sesuatu, dengan adanya motivasi ini karyawan akan memiliki kekuatan pendorong untuk melakukan pekerjaan. Karyawan akan memiliki kinerja yang baik jika pelaksanaan kerjanya didukung kemampuan yang memadai dan dibutuhkan motivasi.

\section{Komunikasi}

Komunikasi yang efektif akan memudahkan pertukaran informasi yang relevan dengan pekerjaan dan akan memperbaiki pelaksanaan kerja organisasi. Dalam komunikasi efektif dibutuhkan pengetahuan, dituntut tidak hanya memahami prosesnya tetapi juga mampu menerapkan pengetahuan secara kreatif (Robbins, 2003). Komunikasi yang efektif mencakup kepercayaan yang dianut, kecermatan yang dirasakan, hasrat akan interaksi, kemauan menerima dari manajemen puncak dan persyaratan informasi keatas, membutuhkan kepekaan dan ketrampilan yang hanya dapat dilakukan setelah mempelajari proses komunikasi dan kesadaran apa yang dilakukan saat berkomunikasi. Banyak perbedaan yang terdapat diantara individuindividu, suasana psikologis organisasi dan kurangnya kemudahan yang memadai selalu mempengaruhi komunikasi. Sehingga untuk berkomunikasi secara efektif dan berhasil, karyawan dan pimpinan harus belajar untuk menghormati satu sama lain dan menghargai serta memahami sebagai manusia yang berbeda.

Terdapat lima hambatan komunikasi yaitu : (1)kurang memperhatikan pengalaman orang lain, (2)penggunaan istilah yang tidak 
dimengerti penerima pesan, (3)pemilihan media yang salah (4)gangguan disekeliling dan (5)penggunaan kata-kata yang mempunyai arti ganda.

\section{Kepuasan Kerja}

Kepuasan kerja merupakan seperangkat perasaan karyawan tentang menyenangkan atau tidak menyenangkan terhadap pekerjaan mereka yang tercermin dalam sikap positif/negatif saat karyawan memandang pekerjaannya, seperti diungkapkan Handoko (2000) bahwa faktor kepuasan dapat menggerakkan motivasi yang dapat meningkatkan prestasi yang baik.

Kepuasan kerja sebagai sikap individu sehubungan dengan jabatan dan pekerjaan yang muncul dari persepsi mereka terhadap bermacam-macam aspek jabatan seperti : imbalan, peluang promosi, supervisor, rekan sekerja. Demikian pula dengan lingkungan pekerjaan seperti gaya supervisor, kebijaksanaan prosedur, afiliasi kelompok kerja, kondisi kerja, imbalan diluar gaji.

Kepuasan kerja merupakan dampai dari adanya pelaksanaan pekerjaan dimana kepuasan dapat diinterpretasikan dan diekspresikan secara lebih akurat dengan nada emosional karyawan dan dilihat dari kesesuaian antara harapan individu mengenai pekerjaannya dan imbalan yang diberikan atas pekerjaan tersebut.

\section{Kinerja}

Kinerja merupakan hasil kerja yang dapat dicapai oleh seseorang atau sekelompok orang dalam suatu organisasi, sesuai dengan wewenang dan tanggungjawab masing-masing. Kinerja individu adalah dasar kinerja organisasi (Gibson, et al., 1994) dan untuk memaksimalkan kinerja masingmasing individu, berhubungan dengan perilaku individu. Kinerja karyawan akan baik apabila mempunyai keahlian yang tinggi, bersedia bekerja karena digaji atau diberi upah sesuai dengan perjanjian, mempunyai harapan masa depan yang lebih baik, sehingga kinerja sebagai hasil yang diperoleh karyawan berdasarkan ukuran yang berlaku untuk suatu tugas atau pekerjaan yang dilaksanakan dalam waktu tertentu.

Menurut Lopez dalam Swasto (1996), ada korelasi antara kinerja dan kepuasan kerja dengan tingkat signifinasi yang tinggi. Mengukur kinerja karyawan secara umum adalah : (1)kuantitas kerja, (2)kualitas kerja, (3)pengetahuan tentang pekerjaan (4)pendapat atau pernyataan yang disampaikan (5)keputusan yang diambil (6)perencanaan kerja (7)daerah organisasi kerja.

Dari penjelasan tersebut maka dapat dirumuskan hipotesis penelitian sebagai berikut:

H1: Terdapat pengaruh karakteristik individu terhadap kinerja karyawan PT Tambang Batubara Bukit Asam

H2: Terdapat pengaruh komunikasi efektif terhadap kinerja karyawan PT Tambang Batubara Bukit Asam

H3: Terdapat pengaruh kepuasan kerja terhadap kinerja karyawan PT Tambang Batubara Bukit Asam 


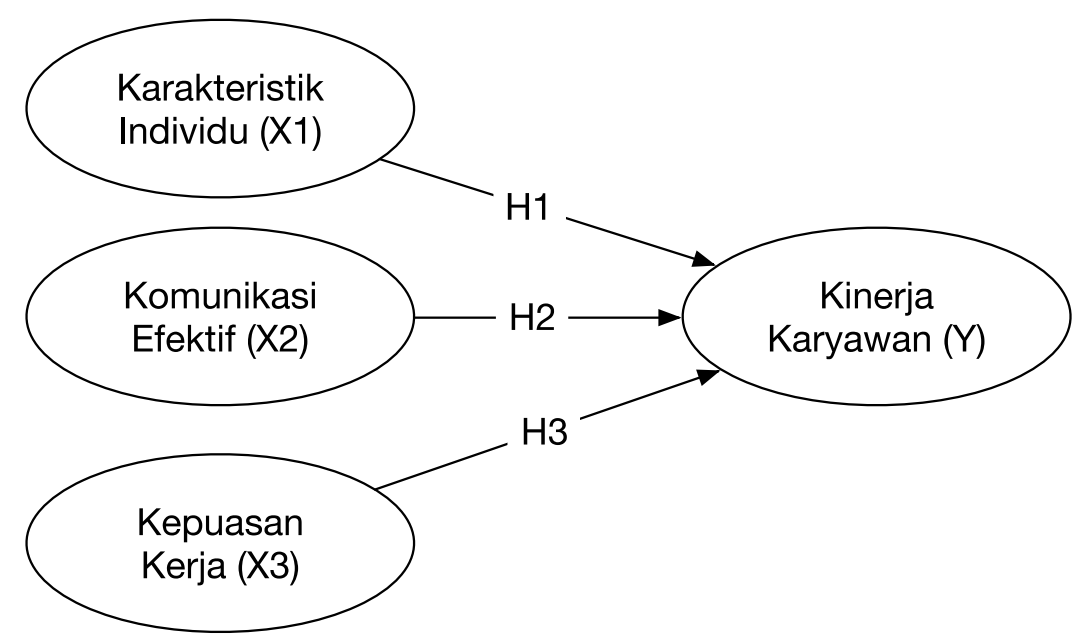

Gambar 1. Kerangka Hipotesis

\section{METODE PENELITIAN}

Jenis Penelitian

Penelitian ini adalah penelitian kuantitatif, dengan pendekatan survey yang meneliti dengan mengambil sampel dari suatu populasi, dengan menggunakan kursioner untuk mengumpulkan data.

\section{Populasi dan Ukuran Sampel Penelitian}

Populasi penelitian ini adalah seluruh karyawan tetap PT Tambang Batubara Bukit Asam yang telah bekerja lebih dari 3 tahun, bukan karyawan kontrak dan bukan karyawan asing serta telah paham dengan pekerjaannya sebesar 392 orang. Untuk mendapatkan besaran sampel digunakan rumus dari Yamane, sebagai berikut :

$$
\mathrm{n}=\frac{\mathrm{N}}{\mathrm{Nd}^{2}+1}
$$

dimana :

$$
\begin{aligned}
\mathrm{n}= & \text { ukuran sampel } \\
\mathrm{N}= & \text { ukuran populasi } \\
\mathrm{d}= & \text { nilai presisi } 10 \% \text { (kelonggaran } \\
& \text { ketidaktelitian) }
\end{aligned}
$$

Berdasarkan rumus tersebut dengan menggunakan nilai presisi $10 \%$, diperoleh besarnya sampel 80 responden dengan menggunakan teknik purposive sampling.

Metode Analisis Data

Analisis data merupakan bagian dari proses pengujian data yang hasilnya digunakan sebagai bukti untuk menarik kesimpulan penelitian yang sesuai dan mudah dipahami. Dengan analisis inferensial dengan pendekatan statistik yang digunakan untuk menganalisis data sampel dan untuk menguji hipotesis yang diajukan, dengan menggunakan Regresi Linier Berganda. Analisis data dimulai dari transformasi data, uji validitas dan reliabilitas, uji asumsi klasik agar diperoleh nilai perkiraan yang tidak bias dan efisien dengan asumsi klasik normalitas, linieritas, multikolinieritas, heterokedastisitas dan autokorelasi.

\section{HASIL DAN PEMBAHASAN}

Hasil Pengujian

Berdasarkan dari hasil pengujian hipotesis pada tabel 1, di dapat luaran sebagai berikut:

$Y=-0,022+0,450 X 1+0,165 X 2+0,347 X 3$

Dari persamaan regresi linear berganda di atas, diketahui bahwa karakteristik memiliki kontribusi positif terhadap kinerja 
karyawan dengan besar pengaruh sebesar 0,450; komunikasi efektif memberikan kontribusi sebesar 0,165; dan kepuasan kerja memberikan kontribusi pengaruh sebesar 0,347. Pembahasan secara rinci dijelaskan sebagai berikut:

\section{Pengaruh karakteristik individu terhadap kinerja karyawan.}

Berdasarkan nilai $t_{\text {hitung }}$ menunjukkan karakteristik individu mempunyai thitung sebesar 4,381, sedangkan $t_{\text {tabel }}$ sebesar 1,665. Jadi $t_{\text {hitung }}>\mathrm{t}_{\text {tabel }}(4,381>1,665)$ dapat disimpulkan bahwa karakteristik individu $\left(\mathrm{X}_{1}\right)$ berpengaruh signifikan terhadap kinerja karyawan (Y). Hal ini menunjukkan bahwa peningkatan $\mathrm{X}_{1}$ akan dapat meningkatkan $\mathrm{Y}$. Dalam hasil analisis regresi, nilai $\mathrm{p}$ (sig t) karakteristik individu terhadap kinerja karyawan diperoleh $0,000<0,10$. Tingkat keberartian pengaruh $\mathrm{X}_{1}$ secara statistik memberikan pengaruh perubahan yang signifikan terhadap Y, artinya H1 diterima.

\section{Pengaruh komunikasi efektif terhadap}

kinerja karyawan PT Tambang Batubara

\section{Bukit Asam}

Berdasarkan nilai thitung menunjukkan komunikasi efektif mempunyai thitung sebesar
2,434, sedangkan $t_{\text {tabel }}$ sebesar 1,665. Jadi $t_{\text {hitung }}>t_{\text {tabel }}(2,434>1,665)$ dapat disimpulkan bahwa komunikasi efektif $\left(\mathrm{X}_{2}\right)$ berpengaruh signifikan terhadap kinerja karyawan (Y). Hal ini menunjukkan bahwa peningkatan $\mathrm{X}_{2}$ akan dapat meningkatkan $\mathrm{Y}$. Dalam hasil analisis regresi, nilai p (sig t) komunikasi efektif terhadap kinerja karyawan diperoleh $0,0173<0,10$. Tingkat keberartian pengaruh $\mathrm{X}_{2}$ secara statistik memberikan pengaruh perubahan yang signifikan terhadap $\mathrm{Y}$, artinya $\mathrm{H} 2$ diterima.

Pengaruh kepuasan kerja terhadap kinerja karyawan PT Tambang Batubara Bukit Asam

Berdasarkan nilai thitung menunjukkan kepuasan mempunyai thitung sebesar 3,419, sedangkan $t_{\text {tabel }}$ sebesar 1,665. Jadi thitung $>$ $t_{\text {tabel }}(3,419>1,665)$ dapat disimpulkan bahwa kepuasan $\left(\mathrm{X}_{3}\right)$ berpengaruh signifikan terhadap kinerja karyawan (Y). Hal ini menunjukkan bahwa peningkatan $\mathrm{X}_{3}$ akan dapat meningkatkan Y. Dalam hasil analisis regresi, nilai $\mathrm{p}(\operatorname{sig} \mathrm{t})$ kepuasan terhadap kinerja karyawan diperoleh 0,0010 < 0,10. Tingkat keberartian pengaruh $\mathrm{X}_{3}$ secara statistik memberikan pengaruh perubahan yang signifikan terhadap $\mathrm{Y}$, artinya $\mathrm{H} 3$ diterima.

Tabel 1. Hasil Pengujian Hipotesis

\begin{tabular}{|c|c|c|c|c|c|c|}
\hline $\begin{array}{c}\text { Variabel } \\
\text { terikat }\end{array}$ & $\begin{array}{c}\text { Variabel } \\
\text { bebas }\end{array}$ & B & $\begin{array}{c}\text { Koefisien } \\
\text { Beta }(\beta)\end{array}$ & $\mathrm{T}$ & Sign $t$ & Keterangan \\
\hline $\mathrm{Y}$ & $\begin{array}{c}\text { X1 } \\
\text { X2 } \\
\text { X3 } \\
\text { Konstanta }\end{array}$ & $\begin{array}{c}0,450267 \\
0,164872 \\
0,346511 \\
-0,022276\end{array}$ & $\begin{array}{l}0,441660 \\
0,167596 \\
0,357888\end{array}$ & $\begin{array}{c}4,381 \\
2,434 \\
3,419 \\
-0,083\end{array}$ & $\begin{array}{l}0,0000 \\
0,0173 \\
0,0010 \\
0,9339\end{array}$ & $\begin{array}{l}\text { diterima } \\
\text { diterima } \\
\text { diterima }\end{array}$ \\
\hline $\begin{array}{l}\text { Multiple } \mathrm{F} \\
\mathrm{R} \text { Square } \\
\text { Adjusted } \mathrm{I} \\
\mathrm{F}_{\text {hitung }} \\
\mathrm{F}_{\text {tabel }} \\
\text { Sign F } \\
\mathrm{T}_{\text {tabel }} \\
\alpha\end{array}$ & $\begin{aligned} & = \\
\text { Square } & = \\
& = \\
& = \\
& =\end{aligned}$ & $\begin{array}{l}5686 \\
3421 \\
372 \\
97902 \\
57 \\
00 \\
55\end{array}$ & & & & \\
\hline
\end{tabular}

Sumber: Data diolah (2017) 
Pembahasan

Karakteristik individu berpengaruh

signifikan terhadap kinerja karyawan PT

Tambang Batubara Bukit Asam

Hasil ini mendukung teori Gibson et al (1996) bahwa individu mempunyai perilaku sebagai ungkapan kepribadian, persepsi, sikap yang bisa berpengaruh terhadap prestasi kerja (kinerja) dirinya dan organisasi. Salah satu faktor yang meningkatkan kinerja adalah motivasi yang dipengaruhi dari dalam dan luar, yang didukung kemampuan, ketrampilan dan pengalaman. Motivasi sebagai sesuatu yang menggerakkan orang, memastikan individu bergerak kearah yang diinginkan. Sasaran motivasi mencapai rasa memiliki tujuan bersama dan memastikan keinginan dan kebutuhan anggotanya dalam keadaan yang harmonis.

Komunikasi efektif berpengaruh signifikan terhadap kinerja karyawan PT Tambang Batubara Bukit Asam

Hasil ini mendukung teori yang dikemukakan oleh Luthan (1995) bahwa karakteristik interpersonal yang efektif mempengaruhi kinerja karyawan yaitu perhatian, ketepatan, deskripsi, kegunaan, ketepatan waktu, kesiapan, kejelasan, kebenaran. Komunikasi sebagai salah satu faktor yang berperan penting dalam meningkatkan dinamika perilaku organisasional secara positif. Hal ini terbukti melalui komunikasi efektif, koordinasi yang mantap dapat diwujudkan, berbagai masalah dapat dipecahkan, informasi dapat tersebar luas dan konflik dapat diselesaikan secara memuaskan (Redding dalam Muhammad, 2000). Dengan komunikasi efektif membantu perkembangan motivasi dengan menjelaskan kepada karyawan, apa yang harus dilakukan, bagaimana bekerja dengan baik dan apa yang dikerjakan untuk memperbaiki kinerja jika masih dibawah standar.

\section{Kepuasan kerja berpengaruh signifikan} terhadap kinerja karyawan PT Tambang Batubara Bukit Asam

Hasil ini mendukung teori yang dikemukakan Robbins (2003) bahwa kepentingan manajer pada kepuasan kerja cenderung berpusat efeknya pada kinerja karyawan. Hubungan kepuasan-kinerja pada hakikatnya "seorang pekerja yang bahagia adalah seorang pekerja yang produktif. Kepuasan sangat penting bagi karyawan, karena menciptakan kesan positif dalam lingkungan kerja organisasi. Dari kesan positif ini tentunya akan membantu karyawan mengembangkan hal-hal baik terhadap pekerjaannya.

\section{KESIMPULAN DAN SARAN}

\section{Kesimpulan}

Berdasarkan hasil penelitian dan pembahasan yang telah dilakukan, dapat diambil kesimpulan sebagai berikut. Karakteristik individu berpengaruh signifikan terhadap kinerja karyawan PT Tambang Batubara Bukit Asam Komunikasi efektif berpengaruh signifikan terhadap kinerja karyawan PT Tambang Batubara Bukit Asam. Kepuasan kerja berpengaruh signifikan terhadap kinerja karyawan PT Tambang Batubara Bukit Asam

\section{Saran}

Terdapat beberapa saran yang diajukan peneliti berdasarkan hasil penelitian, pembahasan dan kesimpulan, diantaranya. Perusahaan hendaknya memperhatikan karakteristik individu yang ada pada karyawan PT Tambang Batubara Bukit Asam, agar dapat menerapkan kebijakan yang berkaitan dengan komunikasi, dengan 
demikian diharapkan dapat menimbulkan kepuasan kerja dan meningkatkan kinerja karyawan. Hendaknya pimpinan atau manajer memperhatikan karyawan dalam melaksanakan pekerjaannya, karena karyawan sebenarnya membutuhkan komunikasi untuk menjalin kedekatan hubungan kerja dengan sesama individu secara perorangan, dalam dinamika kelompok sehingga kinerja akan meningkat pula. Perusahaan hendaknya lebih memperhatikan peranan komunikasi dalam kehidupan berorganisasi, baik antara sesama individu, kelompok maupun pada tingkatan organisasi. Karena dengan adanya komunikasi, akan dapat meningkatkan kepuasan kerja dan meningkatkan kinerja karyawan.
DAFTAR PUSTAKA

Affandy, Zaenal (2000), Pengaruh pemberian motivasi dan gaya komunikasi pemimpin terhadap prestasi kerja karyawan, studi pada industry kecil logam di kabupaten Sidoarjo, tesis Inibraw Malang.

Ancok, Djamaludin (1989), Teknik penyusunan skala pengukur, seri metodologi no.9 Pusat Penelitian Kependudukan Universitas Gadjah Mada, Yogyakarta

Anwar, Saifuddin (2000), Sikap manusia, Teori dan Pengukurannya, edisi kedua, Pustaka Pelajar.

Gibson, Ivancevich dan Donnelly (1996), Organisasi, Perilaku, Struktur, Proses, jilid 1 Binarupa Aksara, Jakarta

, Organisasi, Perilaku, Struktur, Proses, jilid 2 Binarupa Aksara, Jakarta Hardjana, Andre (2000), Audit komunikasi, teori dan praktek, PT Grasindo, Jakarta

Muhammad, Ami (2000), Komunikasi Organisasi, Bumi Aksara, Jakarta

Robbins, Stephen P. )2003), Perilaku Organisasi, Konsep, Kontroversi, Aplikasi, Jilid 2 PT. Prenhallindo, Jakarta 